\title{
Role of Robot-Assisted Partial Nephrectomy for Renal Cell Carcinomas in the Purpose of Nephron Sparing [Corrigendum]
}

Shao IH, Kan HC, Liu CY, et al. Onco Targets Ther. 2019;12:8189-8196.

The authors have advised that there is an error in the Acknowledgments section on page 8195. The correct acknowledgment is as follows:

\section{Acknowledgements}

We would like to thank Research Services Center for Health Information, Chang Gung University,
Taoyuan, Taiwan, for the funding: CMRPG3F0701-2, CMRP-MK 103 No: CIRPD1D0031 and CMRP-MK 104 No: CIRPD1D0032. CORPG3F0291 Kidney Cancer.

The authors apologize for this error.

\section{Publish your work in this journal}

OncoTargets and Therapy is an international, peer-reviewed, open access journal focusing on the pathological basis of all cancers, potential targets for therapy and treatment protocols employed to improve the management of cancer patients. The journal also focuses on the impact of management programs and new therapeutic agents and protocols on patient perspectives such as quality of life, adherence and satisfaction. The manuscript management system is completely online and includes a very quick and fair peer-review system, which is all easy to use. Visit http://www.dovepress.com/ testimonials.php to read real quotes from published authors. 